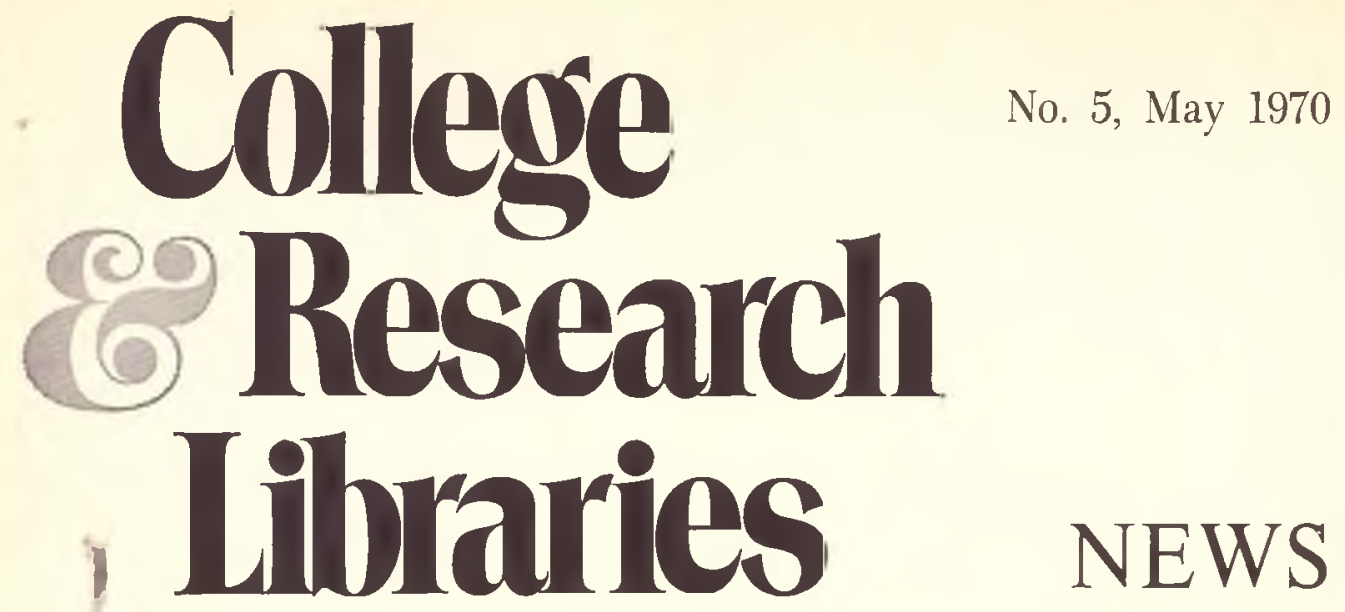

ACRL News Issue (A) of College \& Research Libraries, Vol. 31, No. 3

\title{
Reactions Needed!
}

The following memorandum was transmitted to Mr. David Clift, Executive Director of the American Library Association, to express the views of the Association of College and Research Libraries regarding the American Library Association Activities Committee on New Directions.

ACRL will draw up its final position paper at Detroit. Your views on the reorganization are needed. Would you please send your reactions to Anne Edmonds, Librarian, Mount Holyoke College, South Hadley, Massachusetts 01075; Philip MeNiff, Director, Boston Public Library, Boston, Massachusetts 02117; David Kaser, Director of Libraries, Cornell University, Ithaca, New York 14850; or J. Donald Thomas, Executive Secretary, 50 E. Huron Street, Chicago, Illinois.

\section{MEMORANDUM}

To: David Clift

March 19, 1970

From: J. Donald Thomas

Re: Work of the ALA Activities

Committee on New Directions

I have been requested by the ACRL Executive Committee to inform you that although the Association of College and Research Libraries has not previously reacted to the work of the ALA Activities Committee on New Directions, the division has great concern regarding the findings and recommendations of the cornmittee.

The following lists only the major points to be contained in an official statement which will be issued by ACRL during or shortly after the Detroit Meeting. In the meantime, it is hoped that the Activities Committee will, in its deliberations, give consideration to these recommendations.

1. ALA should remain a strong centralized organization.

2. The present divisions should be reduced to a federation of four types of library divisions representing (a) academic and research libraries, (b) public libraries, (c) school libraries, and (d) special libraries.

3. The present programs of the type of activity divisions and round tables should be absorbed by the four divisions or become the function of various headquarters offices. For example, technical processing and administration are felt to be activities generally handled best by permanent headquarters personnel, and if committees should be needed by such offices, the committees would be appointed by the divisions.

4. The officers of the four divisions would form an advisory committee to the ALA Executive Staff. Meetings would be frequent, and task forces (with terminal dates) would be appointed by such an advisory body to study interdivisional problems.

5. A stronger executive staff for each division is needed with adequate staffing and funding. 
6. The divisions should have more freedom of action in planning and carrying out their primary responsibility to constituents. The Executive Committee of ACRL hopes that no precipitate action is taken by the Committee on New Directions until after the Detroit Meeting.

cc: ACRL Executive Committee

Planning Committee

Board of Directors

घ

\section{INSTRUCTION IN USE OF LIBRARIES COMMITTEE TO MEET IN DETROIT}

The ALA Committee on Instruction in the Use of Libraries will hold a closed meeting during the Detroit Conference at 8:30 P.M. on Monday, June 29. A limited number of guests will be invited to join the Committee in a discussion centered on the recipient of library instruction as he moves from elementary and secondary school through college and/or to life as an out-of-school adult. Persons who would like to participate are urged to write to the chairman, Miss Helen M. Brown, Wellesley College Library, Wellesley, Massachusetts 02181, indicating their interest.

\section{OTTO HARRASSOWITZ Library Agency}

WIESBADEN • GERMANY • POB 349

\section{Direct service on all publications from}

the German language area:

Federal Republic of Germany

German Democratic Republic

Austria Switzerland

\section{Books Serials Periodicals}

Orders and inquiries are invited on both new and out-of-print material

Please request information about our approval plan and blanket order service

Farmington Plan agent for both parts of Germany

OTTO HARRASSOWITZ

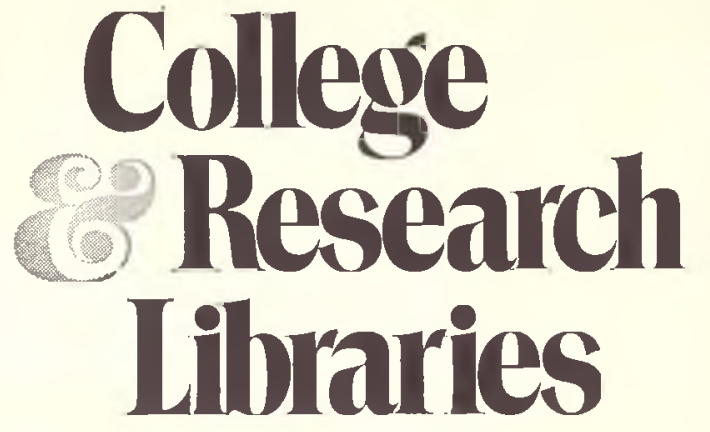

NEWS

News Editor, Michael Herbison, Casper College, Casper, Wyoming 82601.

Editor, Richard M. Dougherty, University of Colorado Libraries, Boulder, Colorado 80302.

Editorial Board: Richaro DeGennaro, Harvard University; David Heron, University of Kansas; Ellsworth Mason, Hofstra University; Fred Hennitz, Southern Connecticut State College; WILliam Axrord, Florida Atlantic University; Peter Hratr, Indiana University.

ACRL Officers, 1969/70: President, Philip J. McNiff; Cbairman, College Libraries Section, John E. Scott; Junior College Libraries Section, Ruthe Erickson; Rare Books Section, Robert J. Adelsperger; Subject Specialists Section, Marcia J. Miller; Agriculture and Biological Sciences Subsection, Howard Rovelstad; Art Subsection, Wolfgang M. Freitag; Educational and Behavioral Science Subsection, Donald Leatherman; Law and Political Science Subsection, Roy M. Mersky; Slavic and East European Subsection, Joseph Placek; University Libraries Section, Roscoe Rouse.

News from the Field, Personnel profiles and notes, classified advertising, official matter of ACRL, and other material of a timely nature is published in the News issues of College of Research Libraries.

Inclusion of an article or advertisement in $C R L$ does not constitute official endorsement by ACRL or ALA. Production and Advertising and Circulation office: 50 E. Huron St., Chicago, IIl. 60611. Change of address and orders for subscriptions should be addressed to College of Research Libraries, for receipt at the above address, at least two months before the publication date of the effective issue.

Subscription to $C R L$ is included in membership dues to $A C R L$ of $\$ 6$ or more; other subscriptions to $C R L$ are $\$ 10$ per year. Neither subscriptions nor memberships include miscellaneous unscheduled supplements, which are available by purchase only. Retroactive subscriptions are not accepted. Single journal copies are available at $\$ 1.50$ each and News issues at $\$ 1.00$ each from ALA Publishing Department.

Indexed in Current Contents, Library Literature, and Science Citation Index. Abstracted in Library Science Abstracts. Book reviews indexed in Book Review Index.

College \& Research Libraries is the official journal of the Association of College and Research Libraries, a division of the American Library Association; and is published seventeen times per year-bi-monthly as a technical journal with 11 monthly News issues, combining July-August-at 1201-05 Bluff St., Fulton, Mo. 65251 .

Second-class postage paid at Fulton, Mo. 